\title{
Phylogeny of Libellulidae(Odonata: Anisoptera): comparison of molecular and morphology-based phylogenies based on wing morphology and migration
}

\author{
Shu T Huang ${ }^{1}$, Hai R Wang ${ }^{2}$, Wan Q Yang ${ }^{1}$, Ya C Si ${ }^{1}$, Yu T Wang ${ }^{1}$, Meng L Sun ${ }^{1}$, Xin Qi ${ }^{1}$, Yi Bai ${ }^{\text {Corresp. } 1}$ \\ ${ }^{1}$ Zhejiang Provincial Key Laboratory of Plant Evolutionary Ecology and Conservation, Taizhou University, Taizhou, Zhejiang, China \\ 2 Sports Science Institute, Taizhou University, Taizhou, Zhejiang, China \\ Corresponding Author: Yi Bai \\ Email address: baiyi@tzc.edu.cn
}

Background: Establishing the species limits and resolving phylogenetic relationships are primary goals of taxonomists and evolutionary biologists. At present, a controversial question is about interspecific phylogenetic information in morphological features. Are the interspecific relationships established based on genetic information consistent with the traditional classification system? To address these problems, this study analyzed the wing shape structure of 10 species of Libellulidae, explored the relationship between wing shape and dragonfly behavior and living habits, and established an interspecific morphological relationship tree based on wing shape data. By analyzing the sequences of mitochondrial COI gene and the nuclear genes 18S, 28S rRNA and ITS in 10 species of dragonflies, the interspecific relationship was established. Method: The wing shape information of the male forewings and hindwings was obtained by the geometric morphometrics method. The inter-species wing shape relationship was obtained by principal component analysis (PCA) in MorphoJ1.06 software. The inter-species wing shape relationship tree was obtained by cluster analysis (UPGMA) using Mesquite3.2 software. The COI, 18S, ITS and $28 S$ genes of 10 species dragonfly were blasted and processed by BioEdit v6 software. The Maximum Likelihood(ML) tree was established by raxmIGUI1.5b2 software. The Bayes inference (BI) tree was established by MrBayes 3.2.6 in Geneious software. Results: The main difference in forewings among the 10 species of dragonfly was the apical, radial and discoidal regions dominated by the wing nodus. In contrast, the main difference among the hindwings was the apical and anal regions dominated by the wing nodus. The change in wing shape was closely related to the ability of dragonfly to migrate. The interspecific relationship based on molecular data showed that the species of Orthetrum genus branched independently of the other species. Compared to the molecular tree of 10 species, the wing shape clustering showed some phylogenetic information on the forewing shape (with large differences on the forewing shape tree vs. molecular tree), 
and there was no interspecific phylogenetic information of the hindwing shape tree vs. molecular tree. Conclusion: The dragonfly wing shape characteristics are closely related to its migration ability. Species with strong ability to migrate have the forewing shape that is longer and narrower, and have larger anal region, whereas the species that prefer shortdistance hovering or standing still for a long time have forewing that are wider and shorter, and the anal region is smaller. Integrating morphological and molecular data to evaluate the relationship among dragonfly species shows there is some interspecific phylogenetic information in the forewing shape and none in the hindwing shape. The forewing and hindwing of dragonflies exhibit an inconsistent pattern of morphological changes in different species. 


\section{Phylogeny of Libellulidae(Odonata: Anisoptera):}

\section{2 comparison of molecular and morphology-based phylogenies}

3 based on wing morphology and migration

4 Shuting Huang ${ }^{1}$, Hairui Wang ${ }^{2}$, Wanqin Yang ${ }^{1}$, Yachu $\mathrm{Si}^{1}$, Yutian Wang ${ }^{1}$, Menglian Sun ${ }^{1}$, Xin

$5 \mathrm{Qi}^{1}, \mathrm{Yi} \mathrm{Bai}^{1}$

6

7 'hejiang Provincial Key Laboratory of Plant Evolutionary Ecology and Conservation, Taizhou

8 University, Taizhou, Zhejiang, China

$9 \quad{ }^{2}$ Sports Science Institute, Taizhou University, Taizhou, Zhejiang, China

10

11 Corresponding Author:

12 Yi Bai $^{1}$

13 Jiazhi Street, Taizhou, Zhejiang, 318000, China

14 Email address: baiyi@tzc.edu.cn

15

16

\section{Abstract}

Background: Establishing the species limits and resolving phylogenetic relationships are primary goals of taxonomists and evolutionary biologists. At present, a controversial question is about interspecific phylogenetic information in morphological features. Are the interspecific relationships established based on genetic information consistent with the traditional classification system? To address these problems, this study analyzed the wing shape structure of 10 species of Libellulidae, explored the relationship between wing shape and dragonfly behavior and living habits, and established an interspecific morphological relationship tree based on wing shape data. By analyzing the sequences of mitochondrial COI gene and the nuclear genes $18 S$, $28 S$ rRNA and ITS in 10 species of dragonflies, the interspecific relationship was established. Interspecific phylogenetic information regarding wing shape structure was analyzed.

Method: The wing shape information of the male forewings and hindwings was obtained by the geometric morphometrics method. The inter-species wing shape relationship was obtained by principal component analysis (PCA) in MorphoJ1.06 software. The inter-species wing shape relationship tree was obtained by cluster analysis (UPGMA) using Mesquite3.2 software. The COI, $18 S$, ITS and $28 S$ genes of 10 species dragonfly were blasted and processed by BioEdit v6 
32 software. The Maximum Likelihood (ML) tree was established by RaxmlGUI1.5b2 software. The

33 Bayes inference (BI) tree was established by MrBayes 3.2.6 in Geneious software.

34 Results: The main difference in forewings among the 10 species of dragonfly was the apical, radial and discoidal regions. In contrast, the main difference among the hindwings was the apical and anal regions. The change in wing shape was closely related to the ability of dragonfly to migrate. The interspecific relationship based on molecular data showed that the species of Orthetrum genus branched independently of the other species. Compared to the molecular tree of 10 species, the wing shape clustering showed some phylogenetic information on the forewing shape (with large differences in the forewing shape tree vs. molecular tree), and there was no interspecific phylogenetic information of the hindwing shape tree vs. molecular tree.

Conclusion: The dragonfly wing shape characteristics are closely related to its migration ability. Species with strong ability to migrate have the forewing shape that is longer and narrower, and have larger anal region, whereas the species that prefer short-distance hovering or standing still for a long time have forewing that are wider and shorter, and the anal region is smaller. Integrating morphological and molecular data to evaluate the relationship among dragonfly species shows there is some interspecific phylogenetic information in the forewing shape and none in the hindwing shape. The forewing and hindwing of dragonflies exhibit an inconsistent pattern of morphological changes in different species.

\section{Introduction}

6 The morphological evolution of insects and the formation of species have been the scientific issues that taxonomists, evolutionary biologists and ecologists are constantly exploring (Misof et al., 2014; Crispo, 2008; Ho \& Zhang, 2018). In natural selection and adaptation, insects have formed diverse phenotypic characteristics and genetic structure (Lundsgaard-Hansen, Matthews \& Seehausen, 2014; Schneider, 2000). With the continuous development and improvement of modern molecular biology technology, establishing reliable inter-species ancestry from a genetic perspective has been well documented (Mack \& Nachman, 2017; Soria-Carrasco et al., 
63 2014; Gompert et al., 2014). However, the traditional classification system is based on the

64 morphological characteristics of the species. Currently, the hot issue to be explored is whether

65 the interspecific relationships established by morphological features can be supported by the

66 molecular data or, in other words, to what extent the current classification system is supported

67 (Virgilio et al., 2010; Lukhtanov, Sourakov \& Zakharov, 2016; Renaud, Savage \& Adamowicz,

68 2012). In the last decade, the traditional views have been that morphological characteristics that

69 involve ecological adaptation and behavioral problems (such as living in the same ecological

70 niche and having similar feeding behaviors and patterns of movement) lead to morphological

71 similarities (Stern \& Orgogozo, 2008). The genetic diversity may not necessarily be related to

72 morphological differences (Robertson, 1959; Wlikens, 1971). However, in recent decades,

73 studies in molecular biology and developmental biology have suggested that mutations in gene

74 expression regulation may promote phenotypic evolution, especially the change in

75 morphological characteristics (Kaessmann, 2010; Rabosky, 2012; Crispo, 2008). It indicates that

76 the differences in the genetic structure are predictable, and to a certain extent, they will result in

77 differences in the morphological structure. These contradictory views are common in evolution

78 of the related species of insects (Victor \& Zúñiga, 2016; Heikkilä et al., 2015). In recent years,

79 with the constant development and improvement of morphological measurement technology, the

80 geometric morphometrics represents a powerful tool to investigate further the shape evolution in

81 systematics (Klingenberg \& Marugán-Lobón, 2013). Geometric morphometrics is an advanced

82 method of morphological analysis in biology; based on the curve, landmark point and semi-

83 landmark point data of the homologous locus concept, it can accurately quantify the phenotypic

84 traits of organisms and explore the morphological evolution of populations (Cooke \& Terhune,

85 2015; Baylac, Villemant \& Simbolotti, 2003).

86 A large number of studies have shown that the morphology-based interspecific relationship

87 is basically consistent with the interspecific relationship established by molecular data when the

88 morphological characteristics are selected judiciously (Grzywacz et al. 2017; Noguerales,

89 Cordero \& Ortego, 2018). Marin et al. (2017) showed that the interspecific relationship of

90 Nymphalidae based on wing shape and wing vein was consistent with that based on molecular

91 data. It indicated the existence of phylogenetic information in the insect wing morphology.

92 Francischini et al. (2017) used COI gene and female genital structure to illustrate the

93 interspecific relationship of Diatraea by the molecular and morphological methods, and the 
94 results obtained by the two methods were consistent in the classification of the interspecific 95 relationships. Similar studies were conducted by Ortego, Aguirre \& Cordero (2012) on the

96

97

98

99

100

101

102

103

104

105

106

107

108

109

110

111

112

113

114

115

116

117

118

119

120

121

122

123

124

population differentiation of Mioscirtus wagneri locust in different geographical regions by

using quantitative morphological features (anterior and posterior plates) and mtDNA, suggesting that morphology-based geographical differentiation correlated with geographical differentiation at the molecular level. Therefore, the morphological data and molecular data can support the interrelationships of the major taxonomic groups in animals. However, the establishment of interspecific phylogenetic relationships based on morphology and molecular data can also lead to inconsistent results. For example, Bocek \& Bocek (2017) showed the morphology of beetle pronotum cannot fully support interspecific phylogenetic relationships. Bapst, Schreiber \& Carlson (2018) used molecular and morphological data to study the interspecific relationship of Branchiopoda and found that the morphological data did not have interspecific phylogenetic information. Due to the common phenomenon of convergent evolution of morphological and ecological traits in nature, the morphological traits may only reveal some differences in phenotype of different research objects, but to accurately reflect the phylogenetic relationships among species, the morphological data need to be combined with the molecular data for synthesis.

This research selected 10 species of dragonfly from the same habitat to study their interspecific relationships. Libellulidae belong to Odonata, and have two pairs of large and transparent membranous wings, with the wing veins clearly visible; the shape and direction of the wing veins are often used as an important classification basis for dragonflies (Outomuro, Dijkstra \& Johansson, 2013; Fauziyah et al., 2014; Rajabi et al., 2016). Geometric morphometrics was used to analyze the morphological differences among species. The mitochondrial gene $C O I$ and nuclear genes $18 S$, ITS and $28 S$ were used to analyze the phylogenetic relationships among the species. We analyzed the phylogenetic relationships based on wing-type features as well as on molecular data. Accordingly, this study addressed the following questions: 1) what was the relationship between the characteristics of the wing shape and the behavior of the dragonfly? 2) Did the wing shape and wing vein contain interspecific phylogenetic information? 3) Did forewings and hindwings exhibit a consistent pattern of morphological changes in different species?

\section{Materials \& Methods}


125

126

127

128

129

130

131

132

133

134

135

136

137

138

139

140

141

142

143

144

145

146

147

148

149

150

151

\section{Materials and data acquisition}

1.1 Specimen collection and image acquisition

In order to explore the relationship between the wing shape of different species of dragonfly in Odonata, we collected dragonflies from May to October 2018 at Xikou reservoir $\left(28^{\circ} 48^{\prime} \mathrm{N}\right.$, $\left.121^{\circ} 25^{\prime} \mathrm{E}\right)$ and surrounding areas in Taizhou City. After classification and identification, the males of 10 species of dragonfly were selected for this research. A total of 84 individuals were studied. The species names and numbers are shown in Table 1. The wings of all specimens were spread; then, the left forewing and the left hindwing were taken and pressed between two slides to make slide specimens. The forewings and hindwings were photographed with a Nikon 5100 camera, fixed on a stand. A ruler and a slide specimen were placed on the same horizontal plane for photographing. All photographs were made using the identical camera settings and were saved in a picture format for later use.

Table 1 Species name, genus, subfamily, family and the number of specimens of each species

1.2 Landmark data acquisition

The TPSdig2 software (Rohlf, 2006) was used to digitize wing images of 10 species of Libellulidae, identifying 26 landmarks on the forewing and 27 on the hindwing (in each case, including two on a ruler) (Fig.1). The landmark-based geometric morphometrics method was applied to study the morphological diversity in wing size and shape. We set landmarks at the intersections of wing veins with the wing margin and intersections of cross veins with major veins and vein branch points (Table 2), which was according to Rohlf \& Corti (2000).

Table 2 Definition and numbering of the landmarks

1.3 Wing shape analysis

The forewing and hindwing shape information was input into CoordGen software (Rohlf \& Slice, 1990) in the IMP series package. Based on the ruler, the errors caused by the focal length of the photograph were eliminated, and the datum line was set. To examine wing-shape variation, digitized landmark data were subjected to generalized procrustes superimposition to standardize the size of the landmark configurations and eliminate differences caused by translation and rotation (Adams, Rohlf \& Slice, 2004). All standardized data were converted into a two-dimensional data format. 
Figure 1 Landmarks on the forewing and hindwing of Libellulidae. (A) Landmarks 1 to 24 on forewing, 25 to 26 are rulers; (B) Landmarks 1 to 25 on hindwing, 26 to 27 are rulers

152

153

154

155

156

157

158

159

160

161

162

163

164

165

166

167

168

169

170

171

172

173

174

175

176

177

\section{Methods and Analysis}

2.1Statistical analysis of morphological data

The standardized morphological information data were imported into MorphoJ1.06d software (Klingenberg, 2009), and the morphological changes of 10 species of dragonfly were analyzed by principal component analysis (PCA), Procrustes analysis and Discriminant analysis.

The first two main components were extracted as scatter plots of forewings and hindwings. In the MorphoJ1.06d software, the thin-plate spline analysis (Bookstein, 1989) was performed, and the difference in landmark points was analyzed. The visualized legend was used to show the variation in forewings and hindwings in the first two principal components.

\subsection{Acquisition of molecular data}

The DNA barcode data of 10 species of dragonfly was obtained from the NCBI website. We obtained Cytochrome oxidase subunit I (COI) gene of each species with length of $349 \mathrm{bp}$ and $18 S$ rRNA, Internal Transcribed Space1 (ITS1) + 5.8s rRNA + Internal Transcribed Space2 (ITS2) and $28 S$ rRNA of each species with length of $747 \mathrm{bp}$. All data were imported into BioEdit v6 software for editing, and the built-in clustalw was used to blast sequences (Hall, 1999). Total obtained $C O I+18 s+I T S+28 s$ gene data with a length of $1096 \mathrm{bp}$ was used to construct the Maximum likelihood (ML) tree and the Bayesian inference (BI) tree. The gene sequence numbers and related information are shown in Table 3.

\section{Table 3 Family, subfamily and GenBank number of 10 species of Libellulidae}

2.3Establishment of morphological and molecular phylogenetic trees

In this study, Mesquite 3.2 software (Maddison \& Maddison, 2009) was used to cluster the morphological characteristics of forewings and hindwings of 10 dragonfly species. The cluster analysis was based on the landmark data for forewings and hindwings of each species established as a matrix. The distance among the taxa represented uncorrected distance. Then, the relationships among the populations were further summarized based on the unweighted pairgroup method with arithmetic averages (UPGMA) to build forewing and hindwing shape trees (Ramírez-Sánchez, Luna \& Cramer, 2016). 
The mitochondrial gene $C O I$ and nuclear gene $18 S+I T S+28 S$ were analyzed using ML and

179

180

181

182

183

184

185

186

187

188

189

190

191

192

193

194

195

196

197

198

199

200

201

202

203

204

205

206

207

208

BI, respectively. Best-fit evolutionary models were determined with MEGA6 software (Tamural

et al., 2013); we obtained the GTR $+\mathrm{G}+\mathrm{I}$ model with the lowest Bayesian Information Criterion score, suggesting it was the best-fit model. The ML analysis was done using raxmlGUI1.5b2 (Silvestro \& Michalak, 2012), under a GTRGAMMAI model. The Bootstrap supports and trees were obtained by running rapid bootstrap analysis of 1000 replicates followed by a search for the best scoring ML tree. The BI was done using MrBayes 3.2.6 (Huelsenbeck \& Ronquist, 2001) executed from within Geneious (Kearse et al., 2012). The model used the abovementioned GTR $+\mathrm{G}+\mathrm{I}$ model (Yang, 1994). All BI analyses consisted of $1.1 \times 10^{6}$ generations of Markov Chain Monte Carlo searches containing 4 chains, heated chain temperature of 0.2 and burn-in of 100,000 generations. Compound Dirichlet priors for branch lengths were assigned to avoid branch-length overestimation using the following: prset brlenspr =unconstrained, gammadir(1.0,0.1,1.0,1.0) shapepr=exponential(10.0). Trees were saved every 1,000 generations. The confidence values of the BI tree were presented as the Bayesian posterior probabilities (BPP) in percentages. Phylogenetic analyses were performed for each of the gene sequences. We using Dendroscope 3.6.2 software (Huson et al., 2007) to edit the phylogenetic trees and get tanglegram between phylogeny constructed using morphological data and that constructed using molecular data.

\section{Results}

\section{Morphological differences in forewings and hindwings of 10 species of dragonflies} (Libellulidae)

The wing shape data were analyzed by PCA and centroid size to find out the shape variation (Fig. 2A). The first two PCs accounted for $35.09 \%$ and $21.77 \%$ of the variation, with the cumulative variation explaining $56.86 \%$ of the total shape variation in forewings. Procrustes analysis (Table 4) of forewings showed Deielia phaon and Pantala flavescens to have the smallest distance (0.006), suggesting their forewing shape differences was small. Trithemis aurora and Tramea virginia had the largest distance (0.120), meaning their forewing shape differences were large. Discriminant analysis results showed no significant difference in forewing shapes between Deielia phaon and Pantala flavescens $(P=1.000)$, significant differences between Crocothemis servilia and Orthetrum albistylum $(P=0.023)$ and Crocothemis 
209

210

211

212

213

214

215

216

217

218

219

220

221

222

223

224

225

226

227

228

229

230

servilia and Orthetrum melania $(P=0.042)$, and strongly significant differences among the other species $(\mathrm{P}<0.01)$. A scatter plot (Fig. 2A) of the first and second principal components showed that on the PC1 axis, Trithemis aurora, Pseudothemis zonata and Orthetrum testaceus were mainly distributed on the negative direction, whereas the other seven species were mainly distributed on the positive direction. Taking into account the profile plots of the wing veins (Fig. 3), the differences mainly occurred in the apical region (LM6-8) and the discoidal region (LM1114). On the PC2 axis, Orthetrum melania, Tramea virginia, Trithemis aurora and Pseudothemis zonata were positioned mainly on the negative direction, and the other six dragonfly species were distributed mainly on the positive direction. The forewing profiles (Fig. 3) showed that the differences occurred mainly in the apical (LM6-8) and the radial region (LM8-10). Centroid Size Analysis (Fig. 2B) results showed that Deielia phaon, Pantala flavescens and Acisoma panorpoides had smaller, and Tramea virginia and Orthetrum melania had larger forewings.

\section{Figure 2 PCA (A) and Centroid size analysis (B) of forewings of 10 dragonfly species} (Libellulidae). Ap: Acisoma panorpoides; Pz: Pseudothemis zonata; Pf: Pantala flavescens; Tv: Tramea virginia; Om: Orthetrum melania; Dp: Deielia phaon; Cs: Crocothemis servilia; Ot: Orthetrum testaceus; Ta: Trithemis aurora; Oa: Orthetrum albistylum.

\section{Figure 3 Thin-plate spline analysis of forewing profiles of 10 dragonfly species}

(Libellulidae). Each profile represents the deformations in wing shape in extreme conditions for each PC.

Table 4 The Procrustes distance of forewing and hindwing shapes among 10 species of Libellulidae

The hindwing shape data were analyzed via PCA and Centroid size to find out the shape variation (Fig. 4A). The first two PCs accounted for $37.08 \%$ and $21.41 \%$ of the variation, with the cumulative variation explaining $58.49 \%$ of the total shape variation in hindwings. Procrustes analysis (Table 4) on hindwings showed Crocothemis servilia and Orthetrum testaceus with the smallest distance (0.026), suggesting their hindwing shapes were similar. The Acisoma panorpoides and Tramea virginia had the largest distance (0.132), indicating relatively large differences in their hindwing shapes. Discriminant analysis showed no significant difference in hindwing shapes between Orthetrum melania and Pseudothemis zonata $(\mathrm{P}=0.111)$, significant 
231 differences between Crocothemis servilia and Orthetrum testaceus $(P=0.034)$, Crocothemis

232 servilia and Orthetrum albistylum $(\mathrm{P}=0.046)$ and Crocothemis servilia and Orthetrum melania 233 ( $P=0.014)$, and strongly significant differences between Crocothemis servilia and Pseudothemis 234 zonata $(P=0.001)$ and among the other species $(P<0.01)$. A scatter plot of PC 1 vs. PC2 (Fig. 4A) 235 showed that on the PC1 axis, Orthetrum testaceus, Orthetrum melania, Crocothemis servilia, 236 Deielia phaon, and Acisoma panorpoides were positioned mainly on the positive direction, and 237 the other five dragonfly species were distributed mainly on the negative direction. Taking into 238 account the profile plot of the wing vein (Fig. 5), the differences in hindwings occurred mainly in 239 the anal region (LM13-16). On the PC2 axis, Tramea virginia, Acisoma panorpoides, Orthetrum 240 testaceus, and Deielia phaon were distributed mainly on the positive direction, and the other six 241 species were positioned mainly on the negative direction. The profiles of hindwing veins (Fig. 5) 242 showed that the differences occurred mainly in the apical (LM6-8) and the anal region (LM13243 16). Centroid Size Analysis (Fig. 4B) showed that Deielia phaon and Acisoma panorpoides had 244 smaller hindwings, whereas Tramea virginia and Orthetrum melania had larger hindwings. 245 Combining the results of the two analyses (PCA and Centroid size), the change rules of 246 forewing shape among species were different to those of hindwing shape. For example, the 247 forewing and hindwing shape analysis of Trithemis aurora showed large differences on the PC1 248 axis. In Centroid size analysis, Orthetrum melania had the biggest forewings, but Tramea 249 virginia had the biggest hindwings.

\section{Figure 4 PCA (A) and Centroid size analysis (B) of hindwings of 10 dragonfly species} (Libellulidae). Ap: Acisoma panorpoides; Pz: Pseudothemis zonata; Pf: Pantala flavescens; Tv: Tramea virginia; Om: Orthetrum melania; Dp: Deielia phaon; Cs: Crocothemis servilia; Ot: Orthetrum testaceus; Ta: Trithemis aurora; Oa: Orthetrum albistylum.

\section{Figure 5 Thin-plate spline analysis of hindwing profiles of 10 dragonfly species}

(Libellulidae). Each profile represents the deformations in wing shape in extreme conditions for each PC.

\section{Analysis of interspecific relationships based on molecular data}

Analysis of the interspecific relationship among 10 species of dragonfly by the ML method (Fig. 6) divided them into two main branches, with Orthetrum species (subfamily Libellulinae) 
255 divided into four branches, forming a paraphyletic group. Deielia phaon was on a separate

256 branch, whereas Acisoma panorpoides and Crocothemis servilia were clustered into a branch

257 with a high degree of support (all three species belonging to subfamily Sympetrinae).

258 Pseudothemis zonata was on a separate branch (subfamily Trithemistinae). Pantala flavescens,

259 Tramea virginia and Trithemis aurora were clustered into a branch with a high degree of support

260 (Pantala flavescens and Tramea virginia belonging to subfamily Trameinae, and Trithemis

261 aurora to subfamily Trithemistinae).

262 The phylogenetic tree obtained by the BI method was basically consistent with the

263 relationship tree obtained by the ML method. Although the BI tree divided further the

264 relationship among the seven species in the four paraphyletic groups, the support was not high,

265 so the interspecific relationships obtained by the ML were only considered in this study.

266 3. Comparative analysis between the morphological relationship tree of forewings and

267 hindwings obtained based on the UPGMA method and the interspecific relationship tree

268 based on the ML method

269 The analysis of forewings (Fig. 7) showed that (based on the wing shape) the individuals of

270 each species clustered together first, then clustered with the other species with relatively close

271 morphological relationships. In the morphological tree, the species of genus Orthetrum were

272 grouped together, but were mixed with Crocothemis servilia and Deielia phaon; also, Pantala

273 flavescens and Trithemis aurora were clustered together. These groupings were consistent with

274 the results of molecular-based genetic analysis. However, for some other species, the results of

275 morphological clustering based on forewings were completely different from those based on the 276 molecular relationships.

277 The hindwing shape analysis also showed that individuals within the species could be

278 clustered first (Fig. 8). Compared with the results of the forewing shapes, many similarities were

279 found. For example, Crocothemis servilia and Deielia phaon were also clustered first with

280 Orthetrum, Tramea virginia was a separate branch, and Pseudothemis zonata and Trithemis

281 aurora were clustered into a branch. However, the hindwing shape clustering was completely

282 different from that based on the molecular relationships. In general, even though there was some

283 phylogenetic information in the forewing shape, the relationships based on the molecular data

284 were still substantially different. In contrast, there was no interspecific phylogenetic information

285 in the hindwing shape. 
Figure 6 Bayesian inference tree (A) and maximum likelihood tree (B). The phylogenetic trees were constructed based on molecular data of the mitochondrial COI and nuclear $18 S \mathrm{rRNA}$ $+I T S 1+5.8 S$ rRNA + ITS2 + 28S rRNA genes.

Figure 7 The morphological tree of forewings (A) vs. maximum likelihood phylogram obtained from the molecular data (mitochondrial COI + nuclear $18 S$ rRNA + ITS1 + 5.8S $r R \boldsymbol{N} A+I T S 2+28 S \boldsymbol{r} R \boldsymbol{N} A$ (B). The clustering of the forewing morphological tree on the left was( $(-)$ or was not $(\cdots)$ consistent with the clustering based on the phylogenetic analysis using the molecular data on the right.

Figure 8 The morphological tree of hindwings (A) vs. maximum likelihood phylogram obtained with the molecular dataset (mitochondrial COI + nuclear $18 S$ rRNA + ITS1 + 5.8S rRNA + ITS2 + 28S rRNA (B). The clustering of the hindwing morphological tree on the left was $(-)$ or was not $(\cdots)$ consistent with the clustering based on of the phylogenetic analyses using the molecular data on the right.

\section{Discussion}

\section{Wing shape and migratory habits}

The application of geometric morphometrics method to study wing shape diversity of dragonflies can effectively reveal the relationships among related species (Breuker et al., 2010; Klingenberg, 2016). The PCA results of the forewing shape in this study showed the main difference between the 10 species of dragonfly was in the apical and radial regions as well as the discoidal region. In contrast, the main difference in the hindwing shape was in the apical and the anal regions. Based on the dynamic load in flight, the wing nodus provides stability during stroke, with all the wing veins centered on the wing nodus; hence, nodus plays a key role in wing deformation and is likely subjected to extensive bending and torsion in flight (Rajabi et al., 2017). The surface of the dragonfly's wings forms various hollow and ridge regions (SuárezTovar \& Sarmiento, 2016), so the wing nodus may be affected by bending as well as twisting deformations during flight. The 10 species of dragonfly exhibit large differences in flight behavior in this study, and these differences in behavior might have led to differences in the 
303 wing shape. From the perspective of the wing function, the characteristics of the apical region of 304 dragonfly wing are related to its forward dive and fast flight, playing an important role in long305 distance migration, territorial patrol and courtship competition (Rajabi et al., 2018). Therefore, 306 the difference in wing shape among different species tested in the present study was expressed 307 prominently at the apical region of the wing. Regardless of the forewing or hindwing, the cubital 308 region and the anal region differed greatly among species. From a functional point of view, these

309

310

311

312

313

314

315

316

317

318

319

320

321

322

323

324

325

326

327

328

329

330

331

332

333 two regions are closely related to the migratory ability of dragonflies (Sun \& Bhushan, 2012; Suárez-Tovar \& Sarmiento, 2016 ). It is generally considered that dragonflies with strong migratory ability have larger cubital and anal regions than non-migrating dragonflies (Jongerius \& Lentink 2010; Rajabi et al., 2018).

In this study, the five dragonfly species of Crocothemis servilia, Orthetrum melania, Orthetrum albistylum, Orthetrum testaceus as well as Acisoma panorpoides were distributed mainly on the positive axis of PC1 and PC2. These species had wide and short forewing, with the small anal region of the hindwing. Tramea virginia, Trithemis aurora, Pseudothemis zonata, and Pantala flavescens were distributed mainly on the negative axis of PC1 and PC2. Their forewings were long and narrow, and the anal region of the hindwing was large. According to the research by Rajabi et al. (2018), the species of dragonfly with long and narrow wing were more suitable for migration, whereas those with wide and short wings were more suited to standing still. Among the dragonflies tested in the present study, from the behavioral point of view, Tramea virginia, Trithemis aurora, Pseudothemis zonata, and Pantala flavescens were all species with strong flying ability, conducting stagnation flight and territory patrols, whereas the species Crocothemis servilia, Orthetrum melania, Orthetrum albistylum, Orthetrum testaceus and Acisoma panorpoides would prefer hovering around ponds or standing still for long periods. The results of this study were in good agreement with those of Rajabi et al. (2018), further confirming the relationship between wing shape and migration.

\section{Genus, Subfamily and Family relationships}

This study illustrated the preliminarily relationships among species, genera, subfamilies, and families based on the phylogenetic relationships of 10 species of dragonfly based on the mitochondrial COI gene and the nuclear genes $18 S, 28 S$ rRNA and ITS. Deielia phaon and Pantala flavescens showed a close relationship, even though they belong to different subfamilies; moreover, they formed a paraphyletic group with Acisoma panorpoides and Crocothemis 
334 servillia, belonging to subfamily Sympetrinae. This result is similar to the results of Ware, May

$335 \&$ Kjer (2007) based on the nuclear genes $16 S$ and $28 S r R N A$, and also similar to the results of

336 Kim et al. (2014) based on the mitochondrial COI gene and the nuclear genes $16 S$ and $28 S$ rRNA.

337 In the phylogenetic tree, Pantala flavescens and Trithemis aurora formed a paraphyletic group,

338 indicating a close relationship despite belonging to different subfamilies; this result was similar

339 to those of Ware, May \& Kjer (2007). In this study, the three species of Orthetrum were

340 independent as a branch, and far away from other species. In general, the results of this study

341 were consistent with the results of Kim et al. (2014), Carle, Kjer \& May (2015) and Yong et al.

342 (2016), indicating that the interspecific phylogenetic relationships based on the mitochondrial

343 COI gene and the nuclear genes $18 S, 28 S$ rRNA and ITS were reliable, and that these genes can

344 be used as barcode genes for interspecies classification.

3453 . Evaluation of genetic information on wing shape

346 This study constructed the interspecific relationship trees for the morphological information

347 on forewings and hindwings based on the UPGMA method, and compared them with the

348 phylogenetic trees obtained based on the molecular data by the BI method. The establishment of

349 interspecific relationships using the UPGMA method in morphological analysis can be supported

350 by numerous studies (Ramírez-Sánchez, Luna \& Cramer, 2016; Fouquet et al., 2012; Gvoždík,

351 Moravec \& Kratochvil, 2008; Limsopatham et al., 2018). The UPGMA method is effective in

352 interspecies morphological analysis, although Robinson \& Terhune (2017) suggested the

353 UPGMA method in subspecies analysis, such as morphological relationship between subspecies

354 or geographical populations, might obscure the patterns among individuals by the interobserver

355 and intermethod errors. However, in the interspecific relationship analysis, this method is ideal.

356 Using the UPGMA method in the present study to analyze forewing and hindwing shapes, the

357 individuals of each species were clustered initially into one branch. Then, topological

358 relationships were established with other species. Compared to the intra-species relationships,

359 the interspecific morphological relationship was farther, so they clustered later.

360 Comparing the morphological relationship tree based on the wing shape and the

361 phylogenetic tree based on the molecular data, some relationships, but also many differences,

362 were found. Regarding the forewing shape, the three species of Orthetrum were clustered into a

363 branch, but had Crocothemis servilia and Deielia phaon mixed in. The phylogenetic tree based

364 on molecular data showed that Crocothemis servilia and Deielia phaon (subfamily Sympetrinae) 
365 had a distant relationship with Orthetrum (subfamily Libellulinae). However, from the

366 behavioral point of view, Crocothemis servilia, Deielia phaon and the species of Orthetrum have

367 many similarities, generally living around ponds or streams, resting on grasses and dead

368 branches, or hovering over grass and ponds. Their territorial consciousness is weak and they can

369 coexist with other species. Similar behaviors and habits may be associated with similar forewing

370 and hindwing shapes. In terms of forewing morphology, Pantala flavescens, Trithemis aurora

371 and Pseudothemis zonata were clustered together as one branch, but could not be combined into

372 one branch based on hindwings. From the behavioral point of view, these dragonflies have strong

373 migrating ability that might have influenced clustering based on the morphology. In terms of the

374 molecular data, Pantala flavescens and Trithemis aurora were clustered together as a branch,

375 and were distant from Pseudothemis zonata. These findings showed there was some genetic

376 information in the wing shape, but it was influenced more by the behavior and life habits. Hence,

377 for dragonflies, establishing inter-species relationships based directly on wing shape may be

378 unreliable. Pilgrim \& Vondohlen (2008) studied the phylogenetic relationships of Sympetrinae

379 based on molecular data (mitochondrial loci $16 \mathrm{~S}$ and 12S rRNA) and morphological traits (38

380 wing venation characters); even though the study did not involve direct comparison of

381 phylogenetic trees based on the two types of information, its conclusion was that the

382 characteristics of the wing veins might be useless in the analysis of relationships due to

383 homoplasy. However, morphological and genetic structure may undergo synchronous evolution

384 in other insects, such as the pronotum and genital segments of grasshopper genus Zoniopoda

385 (Pocco et al., 2018), and the wing veins and genital segments of Euptychiina butterflies (Marin

386 et al., 2017), indicating that phylogenetic information may be contained in morphological

387 features of some insects.

388 Because the sample size selected in this study was relatively small and limited to

389 Libellulidae, the results need to be confirmed on a larger and more diverse collection of species.

390 In the future and using a larger sample size, additional morphological features (such as genital

391 segments) need to be examined to achieve a deeper understanding of the relevance among

392 dragonfly interspecific phylogenetic relationships, morphological evolution and genetic

393 differentiation.

\section{Conclusions}


In this article, we analyzed the wing morphology and migration status, and compared the

396 397

398

399

400

401

402

403

404

405

406

407

408

409

410

411

412

413

414

415

416

417

418

419

420

421

422

423

424

425

molecular and morphology-based phylogenies of Libellulidae. The main results are summarized as follows:

(1) The dragonfly wing shape characteristics are closely related to its migration ability. Species with strong ability to migrate have the forewing shape that is longer and narrower, and have larger anal region, whereas the species that prefer short-distance hovering or standing still for a long time have forewings that are wider and shorter, and the anal region is smaller.

(2) Integrating morphological and molecular data to evaluate the relationship among dragonfly species shows there is some interspecific phylogenetic information in the forewing shape. In the morphological tree, the species of genus Orthetrum were grouped together; also, Pantala flavescens and Trithemis aurora were clustered together. These groupings were consistent with the results of molecular-based genetic analysis. However, hindwing shape had almost no interspecific phylogenetic information.

(3) The forewing and hindwing of dragonflies exhibit an inconsistent pattern of morphological changes in different species, For example, Trithemis aurora, Orthetrum melania and Tramea virginia showed large differences in wings shape and centroid size analysis, which may be due to the different functions of forewings and hindwings in flight and to complex behavior of dragonflies.

\section{Acknowledgements}

We thank our institutions for providing infrastructure and other support. We wish to thank Dr. Chao Song for comments and suggestions on DNA sequence analyses and phylogenetic tree construction.

\section{References}

Misof B, Liu S, Meusemann K, Peters RS, Donath A, Mayer C, Frandsen PB, Ware J, Flouri T, Beutel RG, Niehuis O, Petersen M, Izquierdo-Carrasco F, Wappler T, Rust J, Aberer AJ, Aspöck U, Aspöck H, Bartel D, Blanke A, Berger S, Böhm A, Buckley T, Calcott B, Chen J, Friedrich F, Fukui M, Fujita M, Greve C, Grobe P, Gu S, Huang Y, Jermiin LS, Kawahara AY, Krogmann L, Kubiak M, Lanfear R, Letsch H, Li Y, Li Z, Li J, Lu H, Machida R, Mashimo Y, Kapli P, McKenna DD, Meng G, Nakagaki Y, 
426

427

428

429

430

431

432

433

434

435

436

437

438

439

440

441

442

443

444

445

446

447

448

449

450

451

452

453

454

455

456

Navarrete-Heredia JL, Ott M, Ou Y, Pass G, Podsiadlowski L, Pohl H, von Reumont BM, Schütte K, Sekiya K, Shimizu S, Slipinski A, Stamatakis A, Song W, Su X, Szucsich NU, Tan M, Tan X, Tang M, Tang J, Timelthaler G, Tomizuka S, Trautwein M, Tong X, Uchifune T, Walzl MG, Wiegmann BM, Wilbrandt J, Wipfler B, Wong TK, Wu Q, Wu G, Xie Y, Yang S, Yang Q, Yeates DK, Yoshizawa K, Zhang Q, Zhang R, Zhang W, Zhang Y, Zhao J, Zhou C, Zhou L, Ziesmann T, Zou S, Li Y, Xu X, Zhang Y, Yang H, Wang J, Wang J, Kjer KM, Zhou X. 2014. Phylogenomics resolves the timing and pattern of insect evolution. Science 346(6210):763-767 DOI 10.1126/science.1257570.

Crispo E. 2008. Modifying effects of phenotypic plasticity on interactions among natural selection, adaptation and gene flow. Journal of evolutionary biology 21(6):1460-1469 DOI 10.1111/j.1420-9101.2008.01592.x.

Ho WC. Zhang J. 2018. Evolutionary adaptations to new environments generally reverse plastic phenotypic changes. Nature Communitions 9:350 DOI 10.1038/s41467-018-03360-3.

Lundsgaard-Hansen B, Matthews B, Seehausen O. 2014. Ecological speciation and phenotypic plasticity affect ecosystems. Ecology 95(10):2723-2735 DOI 10.1890/13-2338.1.

Schneider CJ. 2000. Natural selection and speciation. PNAS 97(23):12398-12399 DOI 10.1073/pnas.240463297.

Mack KL, Nachman MW. 2017. Gene regulation and speciation. Trends in Genetics 33(1):6880 DOI 10.1016/j.tig.2016.11.003.

Soria-Carrasco V, Gompert Z, Comeault AA, Farkas TE, Parchman TL, Johnston JS, Buerkle CA, Feder JL, Bast J, Schwander T, Egan SP, Crespi BJ, Nosil P. 2014. Stick insect genomes reveal natural selection's role in parallel speciation. Science 344(6185): 738742 DOI 10.1126/science.1252136.

Gompert Z, Lucas LK, Buerkle CA, Forister ML, Fordyce JA, Nice CC. 2014. Admixture and the organization of genetic diversity in a butterfly species complex revealed through common and rare genetic variants. Molecular Ecology 23(18):4555-4573 DOI $10.1111 / \mathrm{mec} .12811$.

Virgilio M, Backeljau T, Nevado B, De Meyer M. 2010. Comparative performances of DNA barcoding across insect orders. BMC Bioinformatics 11:206 DOI 10.1186/1471-2105-11-206.

Lukhtanov VA, Sourakov A, Zakharov EV. 2016. DNA barcodes as a tool in biodiversity research: testing pre-existing taxonomic hypotheses in Delphic Apollo butterflies 
457

458

459

460

461

462

463

464

465

466

467

468

469

470

471

472

473

474

475

476

477

478

479

480

481

482

483

484

485

486

487

(Lepidoptera, Papilionidae). Systematics and Biodiversity 14(6):599-613 DOI 10.1080/14772000.2016.1203371.

Renaud AK, Savage J, Adamowicz SJ. 2012. DNA barcoding of Northern Nearctic Muscidae (Diptera) reveals high correspondence between morphological and molecular species limits. BMC Ecology 12:24 DOI 10.1186/1472-6785-12-24.

Stern DL, Orgogozo V. 2008. The loci of evolution: how predictable is genetic evolution? Evolution 62(9):2155-2177 DOI 10.1111/j.1558-5646.2008.00450.x.

Robertson FW. 1959. Studies in quantitative inheritance. XII. Cell size and number in relation to genetic and environmental variation of body size in Drosophila. Genetics 44(5):869-896.

Wlikens H. 1971. Genetic interpretation of regressive evolutionary processes: studies of hybrid eyes of two Astyanax cave populations (Characidae: Pisces). Evolution 25(3):530-544 DOI 10.1111/j.1558-5646. 1971.tb01913.x.

Kaessmann H. 2010. Origins, evolution, and phenotypic impact of new genes. Genome Research 20(10): 1313-1326 DOI 10.1101/gr.101386.109.

Rabosky DL. 2012. Positive correlation between diversification rates and phenotypic evolvability can mimic punctuated equilibrium on molecular phylogenies. Evolution 66(8):2622-2627 DOI 10.111110.1111/j.1558-5646.2012.01631.x.

Crispo E. 2008. Modifying effects of phenotypic plasticity on interactions among natural selection, adaptation and gene flow. Journal of Evolutionary Biology 21(6):1460-1469 DOI 10.1111/j.1420-9101.2008.01592.x.

Víctor J, Zúñiga G. 2016. Phylogeny of Dendroctonus bark beetles (Coleoptera: Curculionidae: Scolytinae) inferred from morphological and molecular data. Systematic Entomology 41(1):162-177 DOI 10.1111/syen.12149.

Heikkilä M, Mutanen M, Wahlberg N, Sihvonen P, Kaila L. 2015. Elusive ditrysian phylogeny: an account of combining systematized morphology with molecular data (Lepidoptera). BMC Evolutionary Biology 15:260 DOI 10.1186/s12862-015-0520-0.

Klingenberg CP, Marugán-Lobón J. 2013. Evolutionary covariation in geometric morphometric data: analyzing integration, modularity, and allometry in a phylogenetic context. Systematic Biology 62(4):591-610 DOI 10.1093/sysbio/syt025.

Cooke SB, Terhune CE. 2015. Form, function, geometric morphometrics. The Anatomical Record 298(1):5-28. DOI10.1002/ar.23065 
488

489

490

491

492

493

494

495

496

497

498

499

500

501

502

503

504

505

506

507

508

509

510

511

512

513

514

515

516

517

518

Baylac M, Villemant C, Simbolotti G. 2003. Combining geometric morphometrics with pattern recognition for the investigation of species complexes. Biological Journal of the Linnean Society 80(1):89-98. DOI 10.1046/j.1095-8312.2003.00221.x

Grzywacz B, Heller KG, Warchałowska-Śliwa E, Karamysheva TV, Chobanov DP. 2017. Evolution and systematics of Green Bush-crickets (Orthoptera: Tettigoniidae: Tettigonia) in the Western Palaearctic: testing concordance between molecular, acoustic, and morphological data. Organisms Diversity and Evolution 17(1):213-228 DOI 10.1007/s13127-016-0313-3.

Noguerales V, Cordero PJ, Ortego J. 2018. Integrating genomic and phenotypic data to evaluate alternative phylogenetic and species delimitation hypotheses in a recent evolutionary radiation of grasshoppers. Molecular Ecology 27(5):1229-1244 DOI 10.1111/mec.14504.

Marín MA, Peña C, Uribe SI, Freitas AVL. 2017. Morphology agrees with molecular data: phylogenetic affinities of Euptychiina butterflies (Nymphalidae: Satyrinae). Systematic Entomology 42: 768-785 DOI 10.1111/syen.12245.

Francischini FJB, de Campos JB, Alves-Pereira A, Gomes Viana JP, Grinter CC, Clough SJ, Zucchi MI. 2017. Morphological and molecular characterization of Brazilian populations of Diatraea saccharalis (Fabricius, 1794) (Lepidoptera:Crambidae) and the evolutionary relationship among species of Diatraea Guilding. PLoS One 12(11):e0186266 DOI 10.1371/journal.pone.0186266.

Ortego J, Aguirre MP, Cordero PJ. 2012. Genetic and morphological divergence at different spatiotemp al scales in the grasshopper Mioscirtus wagneri (Orthoptera: Acrididae). Journal of Insect Conservation 16(1):103-110 DOI 10.1007/s10841-011-9397-4.

Bocek M, Bocak L. 2017. The comparison of molecular and morphology-based phylogenies of trichaline net-winged beetles (Coleoptera: Lycidae: Metriorrhynchini) with description of a new subgenus. PeerJ 5:e3963 DOI 10.7717/peerj.3963.

Bapst DW, Schreiber HA, Carlson SJ. 2018. Combined Analysis of Extant Rhynchonellida (Brachiopoda) using Morphological and Molecular Data. Systematic Biology 67(1):32-48DOI 10.1093/sysbio/syx049.

Outomuro D, Dijkstra KDB, Johansson F. 2013. Habitat variation and wing coloration affect wing shape evolution in dragonflies. Journal of Evolutionary Biology 26(9):1866-1874 DOI $10.1111 / \mathrm{jeb} .12203$.

Fauziyah S, Alam C, Soesilohadi RC, Retnoaji B, Alam P. 2014. Morphological and mechanical 
519

520

521

522

523

524

525

526

527

528

529

530

531

532

533

534

535

536

537

538

539

540

541

542

543

544

545

546

547

548

549

characterisationof the hindwing nodus from the Libellulidae family of dragonfly (Indonesia). Arthropod Structure and Development 43(5):415-422 DOI 10.1016/j.asd.2014.06.00.

Rajabi H, Ghoroubi N, Malaki M, Darvizeh A, Gorb SN. 2016. Basal complex and basal venation of Odonata wings: structural diversity and potential role in the wing deformation. PLoS One 11(8):e0160610 DOI 10.1371/journal.pone.0160610.

Rohlf FJ. 2006. TpsDig2, version 2.10. Department of ecology and evoluton, State University of New York, Stony Brook, NY. Available at https://life.bio.sunysb.edu/morph.

Rohlf FJ, Corti M. 2000. Use of two-block partial least-squares to study covariation in shape. Systematic Biology 49(4):740-753 DOI 10.1080/106351500750049806.

Rohlf FJ, Slice DE. 1990. Extensions of the procrustes method for the optimal superimposition of landmarks. Systematic Zoology 39(1): 40-59 DOI 10.2307/2992207.

Adams DC, Rohlf FJ, Slice DE. 2004. Geometric morphometrics: Ten years of progress following the revolution. Italian Journal of Zoology 71(1):5-16 DOI

\section{$10.1080 / 11250000409356545$.}

Klingenberg CP. 2009. Morphometric integration and modularity in configurations of landmarks: tools for evaluating a priori hypotheses. Evolution and Development 11(4):405421 DOI 10.1111/j.1525-142X.2009.00347.x.

Bookstein FL. 1989. Principal warps: thin-plate splines and the decomposition of deformations. IEEE Transactions on Pattern Analysis and Machine Intelligence 11(6):567-585 DOI $10.1109 / 34.24792$.

Hall TA. 1999. BioEdit: a user-friendly biological sequence alignment editor and analysis program for Windows 95/98/NT. Nucleic Acids Symposium Series 41:95-98.

Maddison WP, Maddison DR. 2009. Mesquite: a modular system for evolutionary analysis. Evolution 11(5) DOI 10.1234/12345678.

Tamura K, Stecher G, Peterson D, Filipski A, Kumar S. 2013. MEGA6: Molecular evolutionary genetics analysis version 6.0. Molecular Biology and Evolution 30(12): 27252729 DOI 10.1093/molbev/mst197.

Silvestro D, Michalak I. 2012. raxmlGUI: a graphical front-end for RAxML. Organisms Diversity and Evolution 12(4): 335e337 DOI 10.1007/s13127-011-0056-0.

Huelsenbeck JP, Ronquist F. 2001. MRBAYES: Bayesian inference of phylogenetic trees. Bioinformatics 17(8):754-755 DOI 10.1093/bioinformatics/17.8.754. 
550

551

552

553

554

555

556

557

558

559

560

561

562

563

564

565

566

567

568

569

570

571

572

573

574

575

576

577

578

579

580

Kearse M, Moir R, Wilson A, Stones-Havas S, Cheung M, Sturrock S, Buxton S, Cooper A, Markowitz S, Duran C, Thierer T, Ashton B, Meintjes P, Drummond A. 2012. Geneious Basic: an integrated and extendable desktop software platform for the organization and analysis of sequence data. Bioinformatics 28(12):1647-1649DOI 10.1093/bioinformatics/bts199.

Yang Z. 1994. Estimating the pattern of nucleotide substitution. Journal of Molecular Evolution 39(1):105-111 DOI 10.1007/BF00178256.

Huson DH, Richter DC, Rausch C, Dezulian T, Franz M, Rupp R. 2007. Dendroscope: an interactive viewer for large phylogenetic trees. BMC Bioinformatics 8: 460 DOI 10.1186/1471-2105-8-460.

Breuker CJ, Gibbs M, Dongen SV, Merckx T, Dyck HV. 2010. The use of geometric morphometrics in studying butterfly wings in an evolutionary ecological context. Springer Berlin Heidelberg 124:271-287 DOI 10.1007/978-3-540-95853-6_12.

Klingenberg CP. 2016. Size, shape, and form: concepts of allometry in geometric morphometrics. Development genes and evolution 226(3):113-137 DOI 10.1007/s00427-016-0539-2.

Rajabi H, Ghoroubi N, Stamm K, Appel E, Gorb SN. 2017. Dragonfly wing nodus: A one-way hinge contributing to the asymmetric wing deformation. Acta Biomaterialia 60:330-338 DOI 10.1016/j.actbio.2017.07.034.

Suárez-Tovar CM, Sarmiento CE. 2016. Beyond the wing planform: morphological differentiation between migratory and nonmigratory dragonfly species. Journal of Evolutionary Biology 29(4):690-703 DOI 10.1111/jeb.12830.

Rajabi H, Stamm K, Appel E, Gorb SN. 2018. Micro-morphological adaptations of the wing nodus to flight behaviour in four dragonfly species from the family Libellulidae (Odonata: Anisoptera). Arthropod structure \& development 47(4):442-448 DOI 10.1016/j.asd.2018.01.003.

Sun J, Bhushan B. 2012. The structure and mechanical properties of dragonfly wings and their role on flyability. Comptes Rendus Mecanique 340(1-2): 3-17 DOI 10.1016/j.crme.2011.11.003.

Jongerius SR, Lentink D. 2010. Structural analysis of a dragonfly wing. Experimental Mechanics, 50(9): 1323-1334 DOI 10.1007/s11340-010-9411-x.

Ware J, May M, Kjer K. 2007. Phylogeny of the higher Libelluloidea (Anisoptera: Odonata): an exploration of the most speciose superfamily of dragonflies. Molecular phylogenetics and 
581

582

583

584

585

586

587

588

589

590

591

592

593

594

595

596

597

598

599

600

601

602

603

604

605

606

607

608

609

610

611

evolution 45(1):289-310 DOI 10.1016/j.ympev.2007.05.027.

Kim MJ, Jung K, Park NS, Wan X, Kim KJ, Jun J, Yoon TJ, Bae YJ, Sang ML, Kim I. 2014. Molecular phylogeny of the higher taxa of Odonata (Insecta) inferred from COI, 16S rRNA, 28S rRNA, and EF1- $\alpha$ sequences. Entomological Research 44:65-79 DOI 10.1111/17485967.12051.

Carle F, Kjer K, May M. 2015. A molecular phylogeny and classification of Anisoptera (Odonata). Arthropod Systematics and Phylogeny 73(2):281-301.

Yong HS, Song SL, Suana IW, Eamsobhana P, Lim PE. 2016. Complete mitochondrial genome of Orthetrum dragonflies and molecular phylogeny of Odonata. Biochemical Systematics and Ecology 69:124-131 DOI 10.1016/j.bse.2016.09.002.

Ramírez-Sánchez MM, Luna ED, Cramer C. 2016. Geometric and traditional morphometrics for the assessment of character state identity: multivariate statistical analyses of character variation in the genus Arrenurus (Acari, Hydrachnidia, Arrenuridae). Zoological Journal of the Linnean Society 177(4):720-749 DOI 10.1111/zoj.12384.

Fouquet A, Recoder R, Teixeira M Jr, Cassimiro J, Amaro RC, Camacho A, Damasceno R, Carnaval AC, Moritz C, Rodrigues MT. 2012. Molecular phylogeny and morphometric analyses reveal deep divergence between Amazonia and Atlantic Forest species of Dendrophryniscus. Molecular Phylogenetics and Evolution 62(3):826-838 DOI 10.1016/j.ympev.2011.11.023.

Gvoždík V, Moravec J, Kratochvíl L. 2008. Geographic morphological variation in parapatric Western Palearctic tree frogs, Hyla arborea and Hyla savignyi: are related species similarly affected by climatic conditions? Biological Journal of the Linnean Society 95(3):539-556 DOI 10.1111/j.1095-8312.2008.01056.x.

Limsopatham K, Hall MJR, Zehner R, Zajac BK, Verhoff MA, Sontigun N, Sukontason K, Sukontason KL, Amendt J. 2018. A molecular, morphological, and physiological comparison of English and German populations of Calliphora vicina (Diptera: Calliphoridae). PLoS One 13(12):e0207188 DOI 10.1371/journal.pone.0207188.

Robinson C, Terhune CE. 2017. Error in geometric morphometric data collection: Combining data from multiple sources. American Journal of Physical Anthropology 164(1):62-75 DOI 10.1002/ajpa.23257.

Pilgrim EM, Vondohlen C. 2008. Phylogeny of the Sympetrinae (Odonata: Libellulidae): further 
612 evidence of the homoplasious nature of wing venation. Systematic Entomology 33(1):159-174

613 DOI 10.1111/j.1365-3113.2007.00401.x.

614 Pocco ME, Guzmán N, Plischuk S, Confalonieri V, Lange CE, Cigliano MM. 2018.

615 Diversification patterns of the grasshopper genus Zoniopoda Stål (Romaleidae, Acridoidea,

616 Orthoptera) in open vegetation biomes of South America. Systematic Entomology 43(2):290-

617307 DOI 10.1111/syen.12277.

618 Marín MA, Carlos P, Uribe SI, Freitas VL. 2017. Morphology agrees with molecular data:

619 phylogenetic affinities of Euptychiina butterflies (Nymphalidae: Satyrinae). Systematic

620 Entomology 42(4):768-785 DOI 10.1111/syen.12245. 
Figure 1

Landmarks on the forewing and hindwing of Libellulidae

(A) Landmarks 1 to 24 on forewing, 25 to 26 are rulers; (B)Landmarks 1 to 25 on hindwing, 26 to 27 are rulers

A

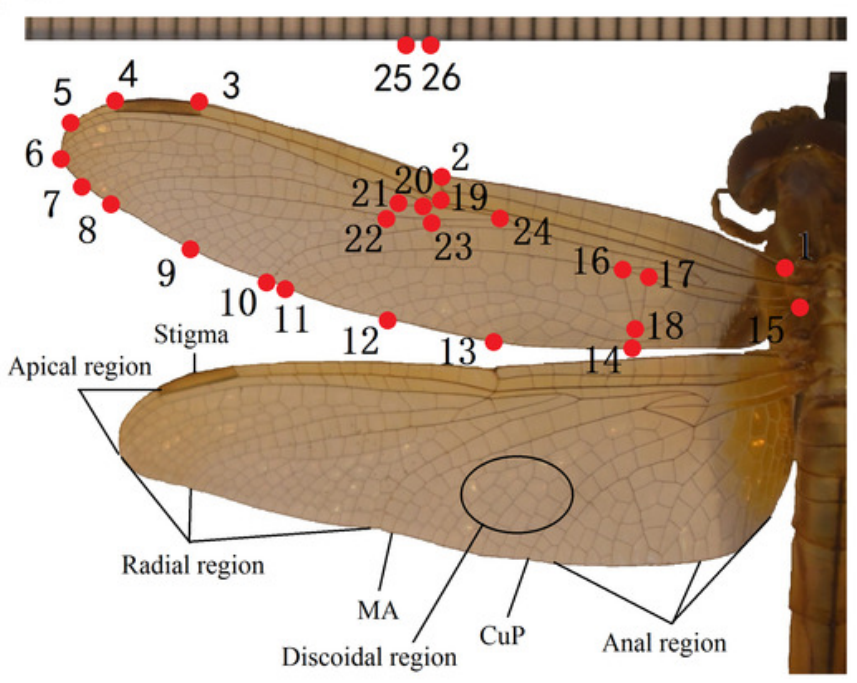

B

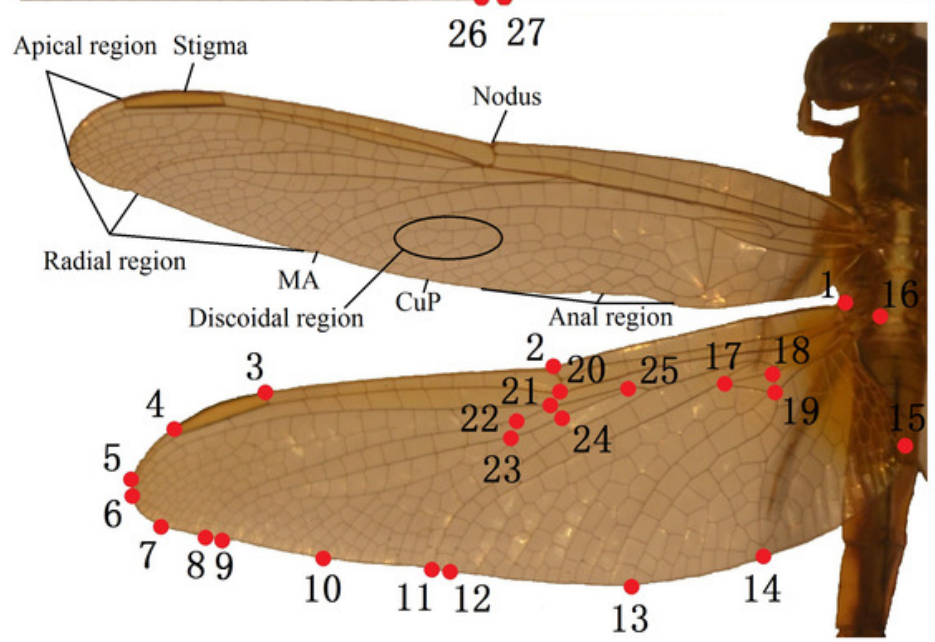


Figure 2

PCA (A) and Centroid size analysis (B) of forewings of 10 dragonfly species (Libellulidae)

Ap: Acisoma panorpoides; Pz: Pseudothemis zonata; Pf: Pantala flavescens; Tv: Tramea

virginia; Om: Orthetrum melania; Dp: Deielia phaon; Cs: Crocothemis servilia; Ot: Orthetrum testaceus; Ta: Trithemis aurora; Oa: Orthetrum albistylum

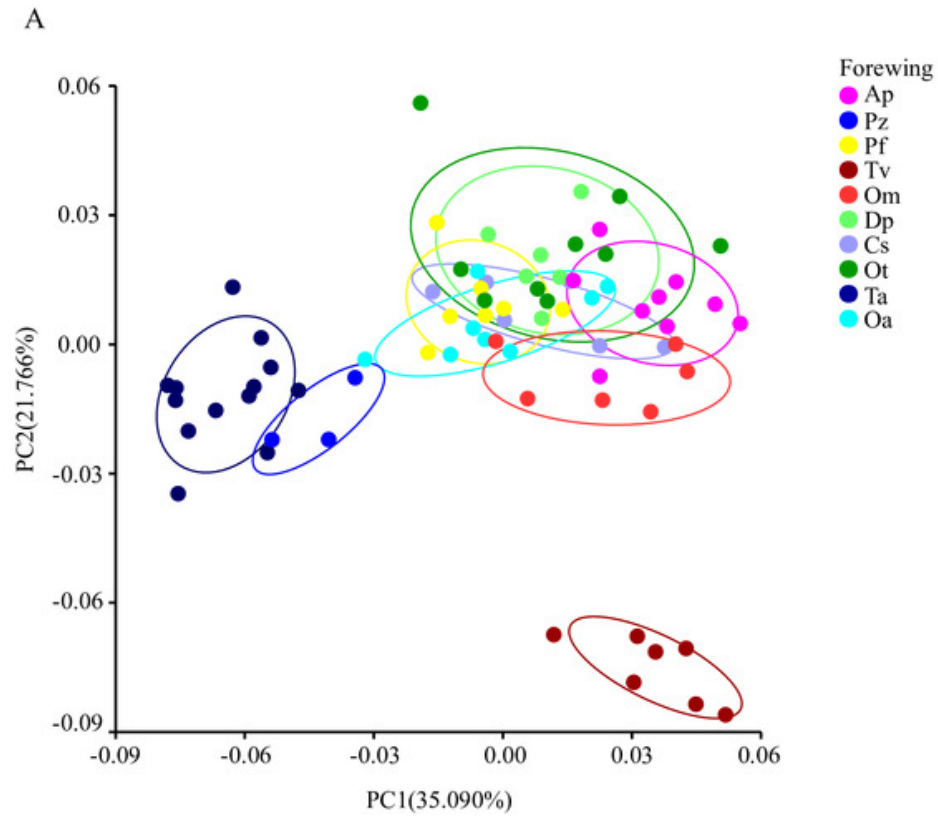

B

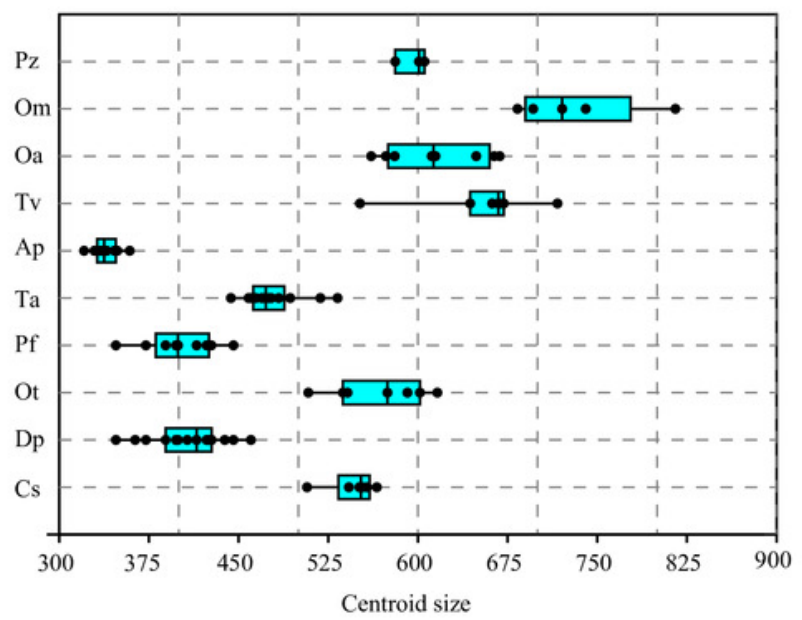


Figure 3

Thin-plate spline analysis of forewing profiles of 10 dragonfly species (Libellulidae)

Each profile represents the deformations in wing shape in extreme conditions for each PC
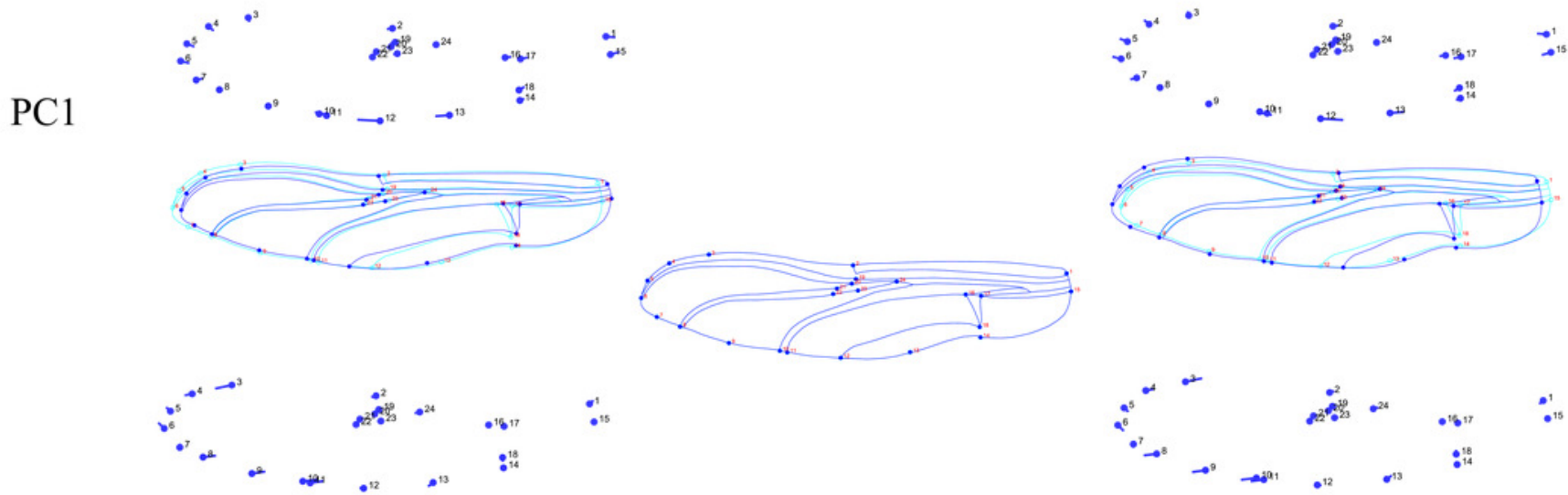

PC2
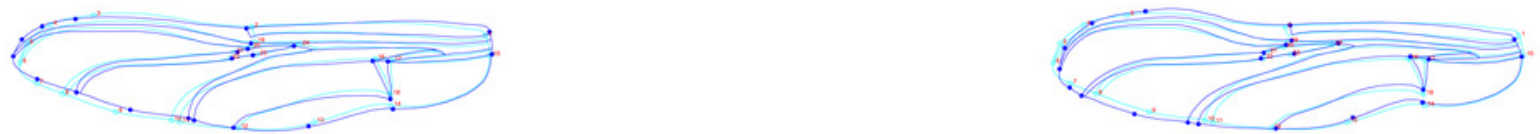

PC-

Mean shape

$\mathrm{PC}+$ 
Figure 4

PCA (A) and Centroid sze analysis (B) of hindwings of 10 dragonfly species (Libellulidae)

Ap: Acisoma panorpoides; Pz: Pseudothemis zonata; Pf: Pantala flavescens; Tv: Tramea

virginia; Om: Orthetrum melania; Dp: Deielia phaon; Cs: Crocothemis servilia; Ot: Orthetrum testaceus; Ta: Trithemis aurora; Oa: Orthetrum albistylum

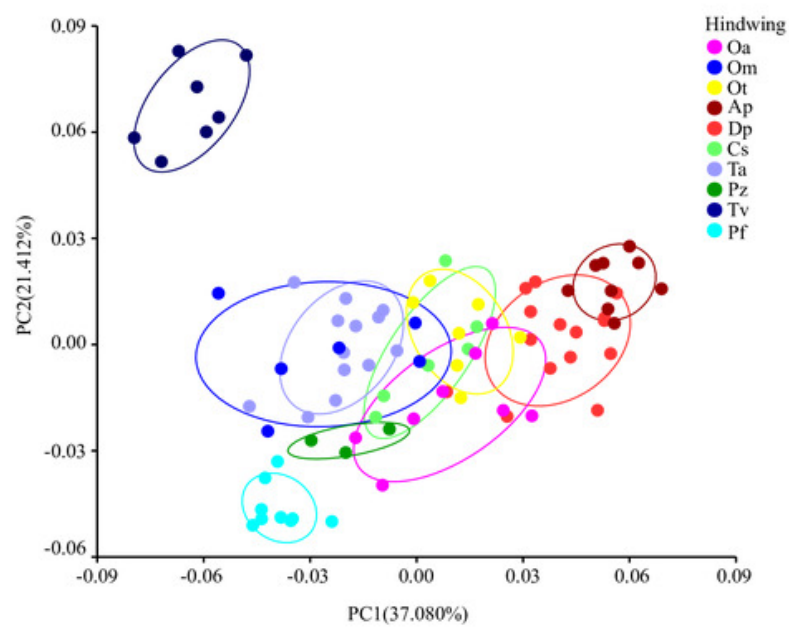

B

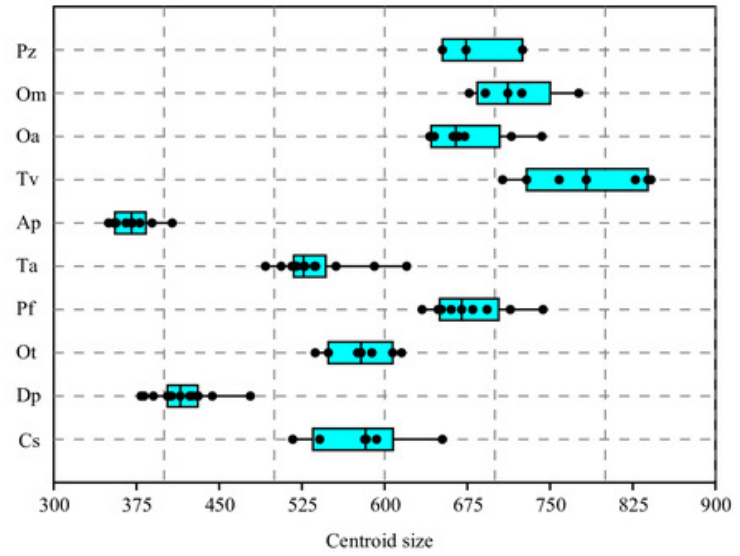


Figure 5

Thin-plate spline analysis of hindwing profiles of 10 dragonfly species (Libellulidae)

Each profile represents the deformations in wing shape in extreme conditions for each PC

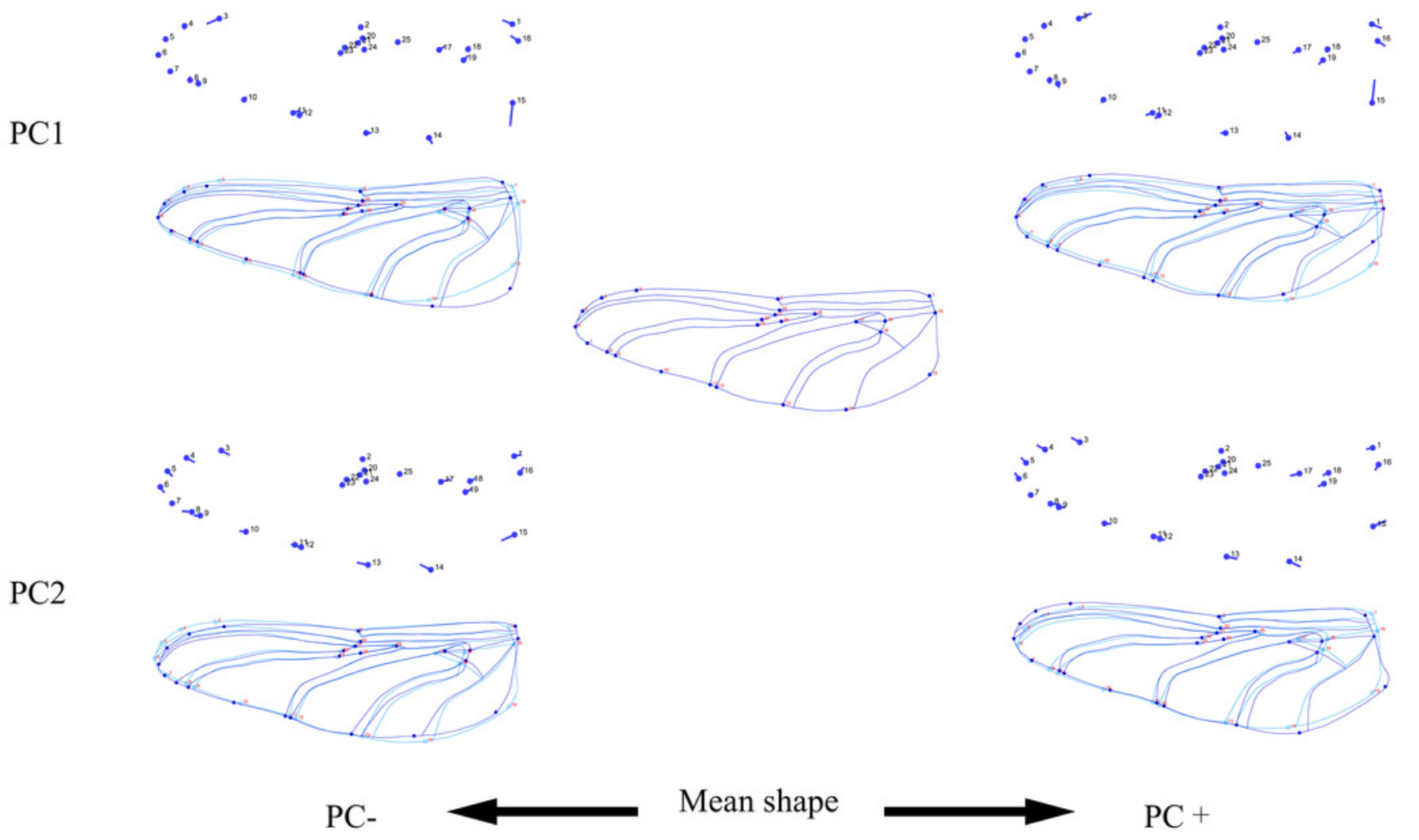


Figure 6

Bayesian Inference tree $(A)$ and maximum likelihood tree (B)

The phylogenetic trees were constructed based on molecular data of the mitochondrial $\mathrm{COI}$ and nuclear 18S rRNA + ITS1 + 5.8S rRNA + ITS2 + 28S rRNA genes

A
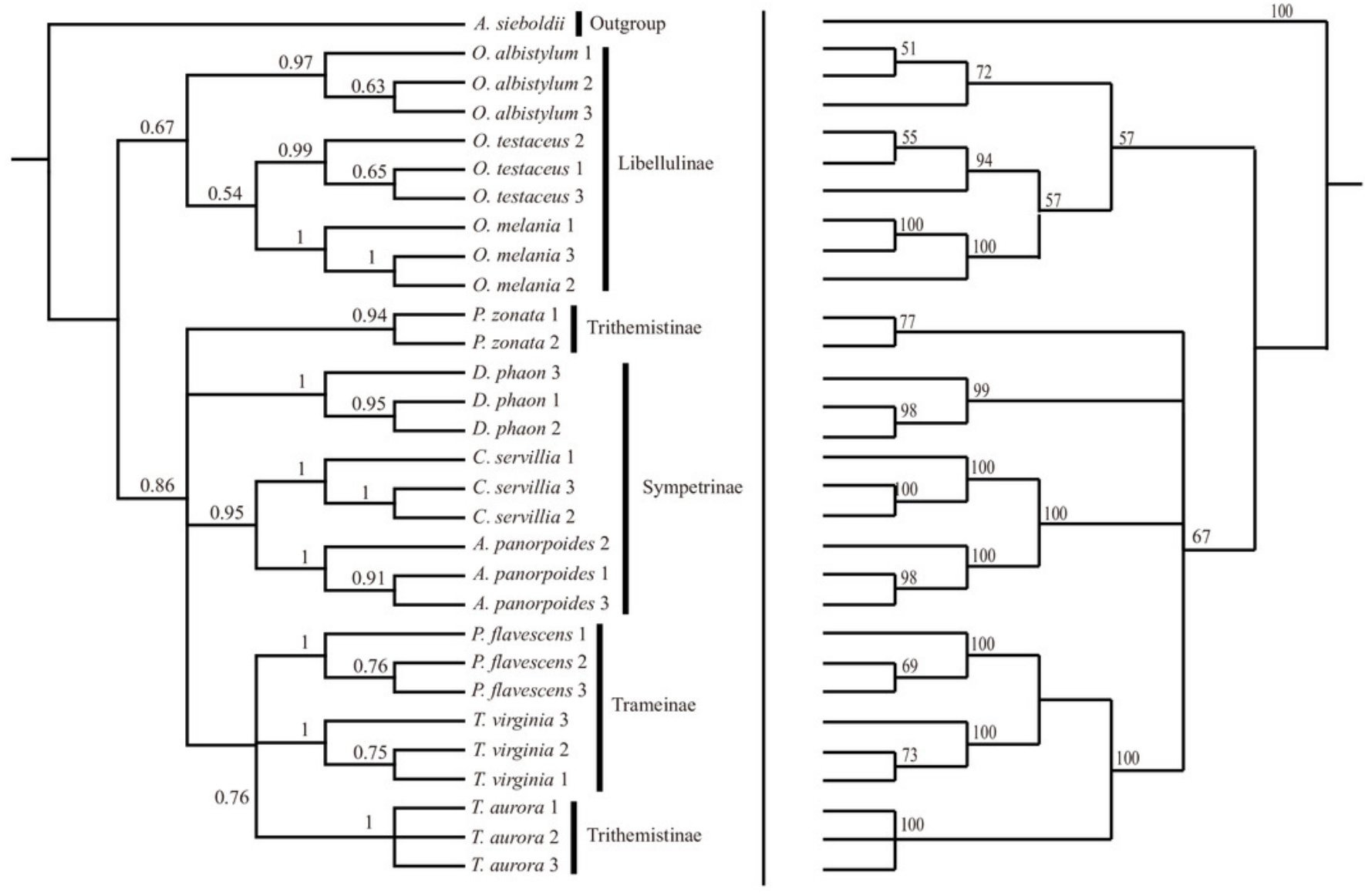
Figure 7

The morphological tree of forewings (A) vs. maximum likelihood phylogram obtained from the molecular data (mitochondrial COI + nuclear 18S rRNA + ITS1 + 5.8S rRNA + ITS2 + 285 rRNA (B)

The clustering of the forewing morphological tree on the left was(-) or was not (...) consistent with the clustering based on the phylogenetic analysis using the molecular data on the right

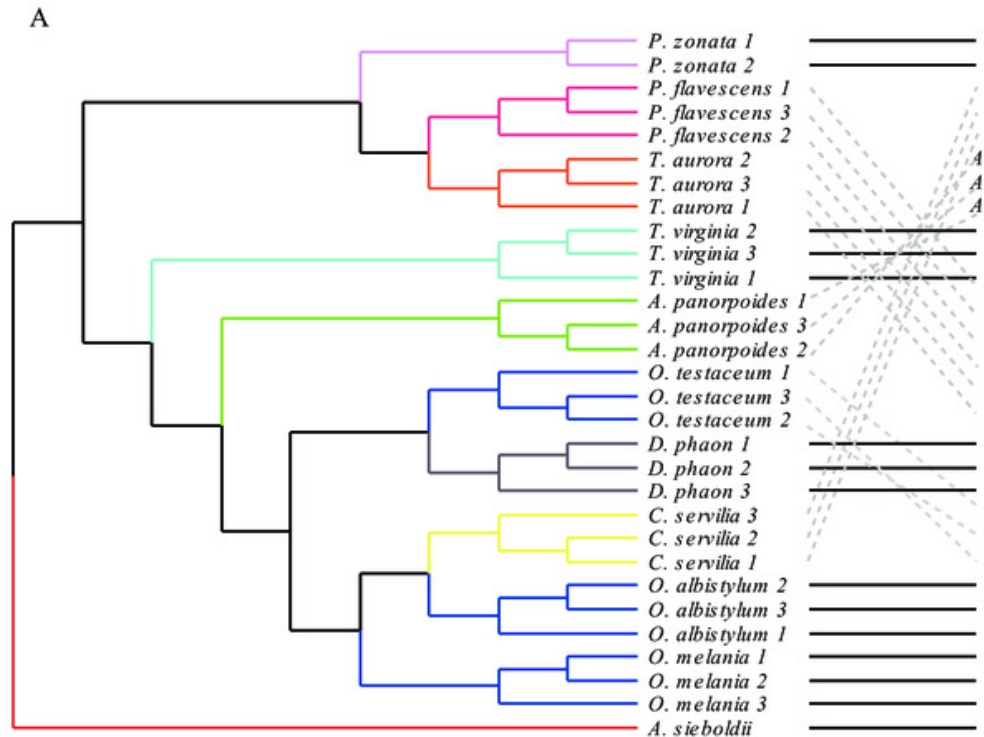

P. zonata 1
P. zonata 2

C. servilia 3

C. servilia 2

panorpoides

A. panorpoides 3

A panorpoides 1

T. virginia 2

T. virginia 3

P. flavescens 1

$P$. flavescens $3-$

$P$. flavescens 2
P.

T. aurora 2

T. aurora 3

T. aurora

D. phaon I

D. phaon 2

D. phaon 3

O. testaceum 1

O.

O. testaceum 3

O. albistylum 3

O. albistylum $3-$

O. albistylum $I$

O. melania 1

O. melania 2

O. melania 3

A. sieboldi 
Figure 8

The morphological tree of hindwings (A) vs. maximum likelihood phylogram obtained with the molecular dataset (mitochondrial COI + nuclear 18S rRNA + ITS1 + 5.8S rRNA + ITS2 + 28S rRNA (B)

The clustering of the hindwing morphological tree on the left was(-) or was not (...)consistent with the clustering based on of the phylogenetic analyses using the molecular data on the right

A
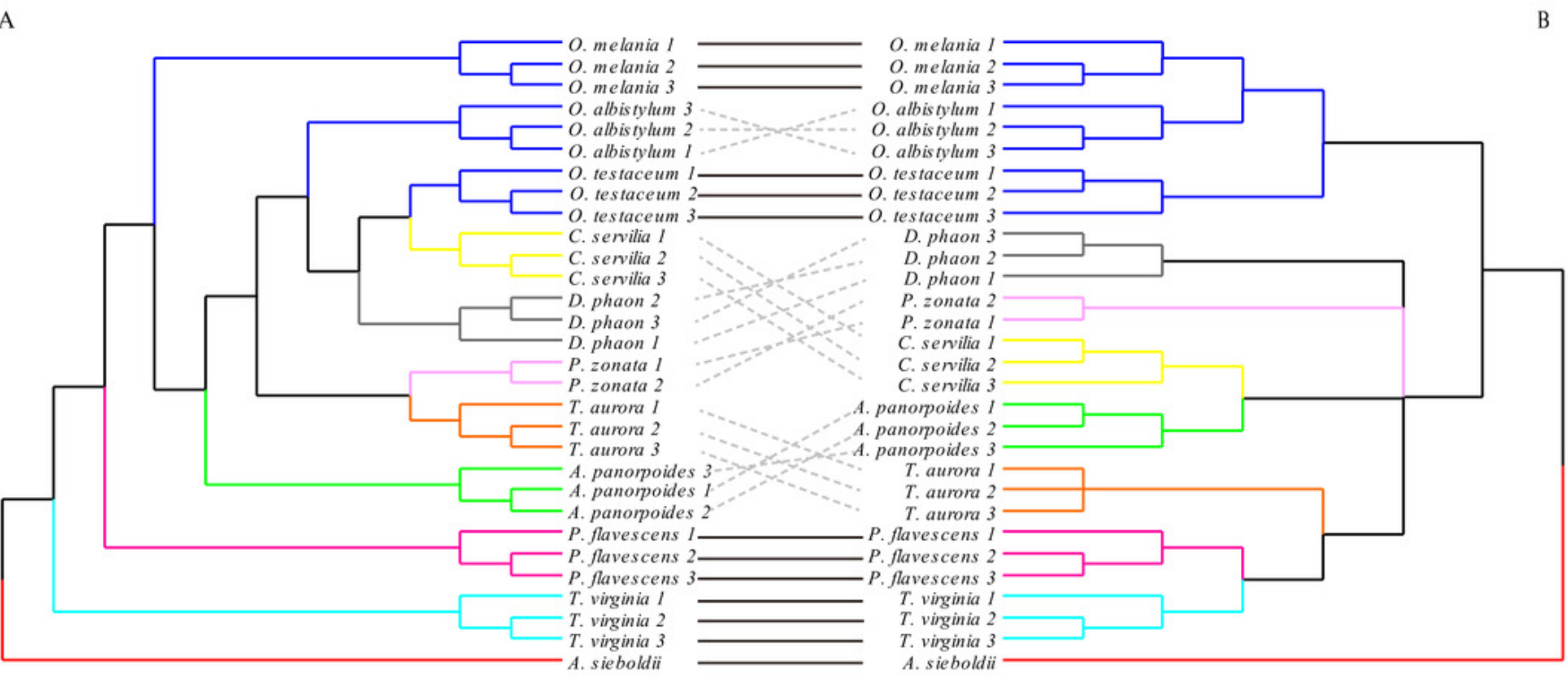


\section{Table $\mathbf{1}$ (on next page)}

The Species name, Genus, Subfamily, Family and number of 10 species of Libellulidae 
1

Table 1 The Species name, Genus, Subfamily, Family and number of 10 species of

Libellulidae

Species

Genus

Subfamily Family

$\mathrm{Nu}$

\begin{tabular}{|c|c|c|c|c|}
\hline Orthetrum albistylum (Selys) & Orthetrum & Libellulinae & Libellulidae & 8 \\
\hline Orthetrum melania (Selys) & Orthetrum & Libellulinae & Libellulidae & 5 \\
\hline $\begin{array}{l}\text { Orthetrum testaceus } \\
\text { (Burmeister) }\end{array}$ & Orthetrum & Libellulinae & Libellulidae & 6 \\
\hline $\begin{array}{l}\text { Acisoma panorpoides } \\
\text { (Rambur) }\end{array}$ & Acisoma & Sympetrinae & Libellulidae & 9 \\
\hline Deielia phaon (Selys) & Deielia & Sympetrinae & Libellulidae & 15 \\
\hline Crocothemis servilia (Drury) & Crocothemis & Sympetrinae & Libellulidae & 6 \\
\hline $\begin{array}{l}\text { Trithemis aurora } \\
\text { (Burmeister) }\end{array}$ & Trithemis & Trithemistinae & Libellulidae & 13 \\
\hline $\begin{array}{l}\text { Pseudothemis zonata } \\
\text { (Burmeister) }\end{array}$ & Pseudothemis & Trithemistinae & Libellulidae & 3 \\
\hline Tramea virginia (Rambur) & Tramea & Trameinae & Libellulidae & 7 \\
\hline $\begin{array}{l}\text { Pantala flavescens } \\
\text { (Fabricius) }\end{array}$ & Pantala & Trameinae & Libellulidae & 9 \\
\hline Anotogaster sieboldii (Selys) & Anotogaster & & Cordulegastridae & 3 \\
\hline
\end{tabular}


Table 2 (on next page)

Definition and numbering of the landmarks 


\begin{tabular}{llll}
\hline \multicolumn{1}{c}{ Table 2} & Definition and numbering of the landmarks & \\
\multicolumn{1}{c}{ L. of forewing } & \multicolumn{1}{c}{ Definition } & L. of hindwing & \multicolumn{1}{c}{ Definition } \\
\hline 1 & Initial of costa & 1 & Initial of costa \\
2 & Nodus & 2 & Nodus \\
3 & Left of stigma & 3 & Left of stigma \\
4 & Right of stigma & 4 & Right of stigma \\
5 & Midpoint of 4 and 6 & 5 & End of sub-costa \\
6 & End of RP1 & 6 & End of RP1 \\
7 & Midpoint of 6 and 8 & 7 & Midpoint of 6 and 8 \\
8 & End of RP2 & 8 & End of RP2 \\
9 & Midpoint of 8 and 10 & 9 & End of IRP2 \\
10 & End of RP3-4 & 10 & Midpoint of 9 and 10 \\
11 & End of MA & 11 & End of RP3-4 \\
$12-14$ & Anal region & 12 & End of MA \\
15 & End of the anal vein & 13 & End of CuP \\
$16-18$ & triangle region & $14-15$ & Anal region \\
$19-20$ & Sub-nodu & 16 & End of the anal vein \\
$21-24$ & Midvein region & $17-19$ & triangle region \\
& & $20-21$ & Sub-nodu \\
& & $22-25$ & Midvein region \\
\hline
\end{tabular}




\section{Table 3 (on next page)}

The Famliy, Subfamily and GenBank number of 10 species of Libellulidae 
Table 3 The Famliy, Subfamily and GenBank number of 10 species of Libellulidae

GenBank number

\begin{tabular}{|c|c|c|c|c|}
\hline Family & Subfamily & Species & $\begin{array}{l}\text { Mitochondria } \\
\text { COI }\end{array}$ & $\begin{array}{l}\text { Nuclear } 18 S \\
r R N A+I T s 1+5.8 s \\
+I T s 2+28 S \text { rRNA }\end{array}$ \\
\hline Libellulidae & Libellulinae & Orthetrum albistylum & MF358741.1 & LC366177.1 \\
\hline Libellulidae & Libellulinae & Orthetrum albistylum & MF358740.1 & AB781474.1 \\
\hline Libellulidae & Libellulinae & Orthetrum albistylum & MF358739.1 & AB781473.1 \\
\hline Libellulidae & Libellulinae & Orthetrum melania & LC099937.1 & LC099933.1 \\
\hline Libellulidae & Libellulinae & Orthetrum melania & AB709043.1 & AB707165.1 \\
\hline Libellulidae & Libellulinae & Orthetrum melania & AB709085.1 & AB707187.1 \\
\hline Libellulidae & Libellulinae & Orthetrum testaceus & KU496907.1 & KJ802972.1 \\
\hline Libellulidae & Libellulinae & Orthetrum testaceus & KU496905.1 & KJ802970.1 \\
\hline Libellulidae & Libellulinae & Orthetrum testaceus & MF774527.1 & KJ802969.1 \\
\hline Libellulidae & Sympetrinae & Acisoma panorpoides & KX281827.1 & AB707046.1 \\
\hline Libellulidae & Sympetrinae & Acisoma panorpoides & KX281825.1 & AB707045.1 \\
\hline Libellulidae & Sympetrinae & Acisoma panorpoides & KX281824.1 & FN356030.1 \\
\hline Libellulidae & Sympetrinae & Deielia phaon & AB708961.1 & AB707069.1 \\
\hline Libellulidae & Sympetrinae & Deielia phaon & AB708962.1 & AB707068.1 \\
\hline Libellulidae & Sympetrinae & Deielia phaon & AB708963.1 & AB707066.1 \\
\hline Libellulidae & Sympetrinae & Crocothemis servilia & JN119571.1 & LC366268.1 \\
\hline Libellulidae & Sympetrinae & Crocothemis servilia & MF774561.1 & LC366266.1 \\
\hline Libellulidae & Sympetrinae & Crocothemis servilia & MF774554.1 & LC366265.1 \\
\hline Libellulidae & Trithemistinae & Trithemis aurora & MF358792.1 & AB707343.1 \\
\hline Libellulidae & Trithemistinae & Trithemis aurora & MF358785.1 & AB707342.1 \\
\hline Libellulidae & Trithemistinae & Trithemis aurora & MF358776.1 & GU323038.1 \\
\hline Libellulidae & Trithemistinae & Pseudothemis zonata & MF358738.1 & AB707212.1 \\
\hline Libellulidae & Trithemistinae & Pseudothemis zonata & KF257079.1 & AB707212.1 \\
\hline Libellulidae & Trameinae & Tramea virginia & AB709228.1 & AB707335.1 \\
\hline Libellulidae & Trameinae & Tramea virginia & AB709225.1 & AB707331.1 \\
\hline Libellulidae & Trameinae & Tramea virginia & AB709227.1 & AB707332.1 \\
\hline Libellulidae & Trameinae & Pantala flavescens & KR080133.1 & LC366168.1 \\
\hline Libellulidae & Trameinae & Pantala flavescens & KR080114.1 & AB707211.1 \\
\hline Libellulidae & Trameinae & Pantala flavescens & KR080079.1 & LC366076.1 \\
\hline Cordulegastridae & & Anotogaster sieboldii & EF155476.1 & AB706931.1 \\
\hline
\end{tabular}




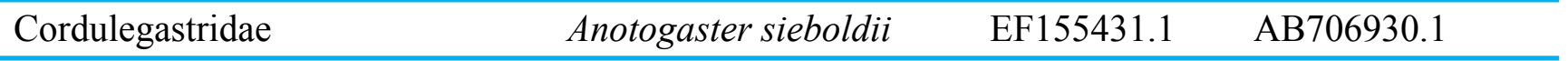

1 
Table 4 (on next page)

The procustes distance of forewing and hindwing shape among 10 species of Libellulidae 
Table 4 The procrustes distance of Forewing and Hindwing shape among 10 species of Libellulidae

\begin{tabular}{|c|c|c|c|c|c|c|c|c|c|c|}
\hline $\begin{array}{l}\text { Hindwing shape } \\
\text { distance } \\
\text { Forewing shape } \\
\text { distance }\end{array}$ & Cs & Dp & Ot & Pf & $\mathbf{T a}$ & Ap & $\mathbf{T v}$ & $\mathbf{O a}$ & Om & $\mathbf{P z}$ \\
\hline \multirow[t]{2}{*}{ Cs } & & 0.05 & 0.02 & 0.083 & 0.05 & $0.079 *$ & 0.10 & 0.034 & 0.04 & 0.05 \\
\hline & & $9 * *$ & 6 & $* *$ & $4 * *$ & $*$ & $7 * *$ & & 5 & 5 \\
\hline \multirow[t]{2}{*}{ Dp } & 0.04 & & 0.05 & 0.096 & 0.07 & $0.044 *$ & 0.12 & 0.051 & 0.07 & 0.07 \\
\hline & $2 * *$ & & $1 * *$ & $* *$ & $4^{* *}$ & $*$ & $4^{* *}$ & $* *$ & $3 * *$ & $4^{*}$ \\
\hline \multirow[t]{2}{*}{ Ot } & 0.03 & 0.04 & & 0.083 & 0.05 & $0.064^{*}$ & 0.10 & 0.040 & 0.05 & 0.05 \\
\hline & $4^{*}$ & $1 * *$ & & $* *$ & $5 * *$ & $*$ & $6^{* *}$ & $* *$ & $1^{*}$ & $6 * *$ \\
\hline \multirow[t]{2}{*}{ Pf } & 0.04 & 0.00 & 0.04 & & 0.06 & $0.116^{*}$ & 0.11 & 0.073 & 0.06 & 0.05 \\
\hline & $1 * *$ & 6 & $2 * *$ & & $8 * *$ & $*$ & $8 * *$ & $* *$ & $3 * *$ & $1 * *$ \\
\hline \multirow[t]{2}{*}{ Ta } & 0.08 & 0.08 & 0.06 & 0.085 & & $0.090 *$ & 0.09 & 0.062 & 0.04 & 0.04 \\
\hline & $2 * *$ & $4 * *$ & $9 * *$ & $* *$ & & $*$ & $3 * *$ & $* *$ & $9 * *$ & $1 * *$ \\
\hline \multirow[t]{2}{*}{ Ap } & 0.06 & 0.04 & 0.06 & 0.046 & 0.10 & & 0.13 & 0.078 & 0.09 & 0.09 \\
\hline & $6 * *$ & $5 * *$ & $0 * *$ & $* *$ & $8 * *$ & & $2 * *$ & $* *$ & $5 * *$ & $6^{*}$ \\
\hline \multirow[t]{2}{*}{$\mathbf{T v}$} & 0.09 & 0.10 & 0.09 & 0.102 & 0.12 & $0.091 *$ & & 0.116 & 0.08 & 0.11 \\
\hline & $4 * *$ & $1 * *$ & $9 *$ & $* *$ & $0 * *$ & $*$ & & $* *$ & $6 * *$ & $2 *$ \\
\hline \multirow[t]{2}{*}{$\mathbf{O a}$} & 0.03 & 0.04 & 0.03 & 0.040 & 0.07 & $0.064 *$ & 0.09 & & 0.04 & 0.05 \\
\hline & 2 & $1 * *$ & $3 * *$ & $*$ & $1 * *$ & $*$ & $4 * *$ & & $8 * *$ & $4 * *$ \\
\hline \multirow[t]{2}{*}{ Om } & 0.03 & 0.05 & 0.05 & 0.058 & 0.09 & $0.076^{*}$ & 0.08 & 0.046 & & 0.04 \\
\hline & 3 & $9 * *$ & $6 *$ & $*$ & $6^{* *}$ & $*$ & $4 * *$ & $*$ & & 1 \\
\hline \multirow[t]{2}{*}{$\mathbf{P z}$} & 0.09 & 0.08 & 0.08 & 0.090 & 0.07 & $0.106^{*}$ & 0.11 & 0.082 & 0.10 & \\
\hline & $4 * *$ & $8 * *$ & $9^{* *}$ & $*$ & $2 *$ & $*$ & $6 *$ & $*$ & $8^{*}$ & \\
\hline
\end{tabular}

1 Notes:

$2 \quad *$ represent significance level $<0.01$, ** represent significance level $<0.001$; Ap: Acisoma

3 panorpoides; Pz: Pseudothemis zonata; Pf: Pantala flavescens; Tv: Tramea virginia; Om:

4 Orthetrum melania; Dp: Deielia phaon; Cs: Crocothemis servilia; Ot: Orthetrum testaceus; Ta:

5 Trithemis aurora; Oa: Orthetrum albistylum.

6 